Apidologie, 1979, 10 (1), 55-62.

\title{
THE SIGNIFICANCE OF ODOR FOR BEES ORIENTING ACROSS A CANYON
}

\author{
Franz Josef BOGDANY* and Stephen TABER, $1 I^{* *}$
}

\begin{abstract}
SUMMARY
Honey bees (Apis mellifera L.) were step-guided across a $1,200 \mathrm{~m}$ wide and $200 \mathrm{~m}$ deep canyon. When scent was added to the food source, approximately three times as many recruits were able to locate the food source on the opposite rim of the canyon as opposed to when no scent was presented. No bees were observed approaching the food source from downwind. The direction the bees were leaving the hive was investigated by placing eight observation stations at different directions and distances from the hive. Recruits were almost exclusively noted at observation stations that were located on a straight line between hive and feeding station.
\end{abstract}

\section{INTRODUCTION}

More than half a century ago, von FRISCH (1923) had noted that odors carried back on the bodies of forager bees provided recruit bees with the information necessary to locate a food source. The role of odors in honey bee orientation has been a focal point in honey bee research since that time (v. FrISCH, 1967a, pp. 257-64 and pp. 491$510)$.

Recently, controversy has arisen about the significance of odor as an orientation cue (v. Frisch, 1976; Lindauer, 1971; WenNer, 1974; Gould, 1976). Challenging von FRISCH's “ dance language hypothesis ", WENNER et al. (1969) stated that recruits can find a food source solely by olfaction and that without odor recruits are unable to locate a food source. In further studies, WeLls and WENNER, 1971; FrIESEN, 1973) it was shown that recruitment of new foragers was increased by addition of an odor to the food, and that the rate of recruit success was decreased drastically when the odor was removed from the food source. FrIESEN (1973) also found that downwind

* Research Fellow of the Deutsche Forschungs Gemeinschaft, W. Germany.

** Research Entomologist, U.S.D.A., S.E.A., Agricultural Research, Carl Hayden Bee Research Center, 2000 E. Allen Road, Tucson, Arizona 85719. 
feeding stations were much more difficult to locate than upwind stations and that recruits preferentially stayed downwind of the flight paths of the forager bees.

Based on these findings, WENNER (1974) modified his " olfaction hypothesis " and WENNER et al., 1969) proposed the " odor population hypothesis". According to this hypothesis, the success of recruits is dependent upon the proper combination of food odor, bee odor and location odor. Recruits are expected to orient by flying upwind along " aerial pathways ", which are formed by the odors of travelling foragers. Wind speed and wind direction, concentration of odor, size of the forager and recruit pools and the distance between hive and food are stressed as critical factors.

Gould (1976) raises the question as to how the "odor population hypothesis " might explain recruitment to food sources downwind from the hive. In our study we investigated whether the "odor population hypothesis " would apply in a crosswind situation.

\section{MATERIALS AND METHODS}

The orientation situation we presented to the bees was the $1,200 \mathrm{~m}$ wide and $200 \mathrm{~m}$ deep Molino Canyon, which is located in the Santa Catalina Mountains, north of Tucson, Arizona (Fig. 1, 2). An airstream originating from the desert at the mouth of the canyon and ascending to the mountains provided a continuous crosswind of about $5-10 \mathrm{~m} / \mathrm{s}$ that blew at a $90^{\circ}$ angle to the line across the canyon. The experiments were conducted during August 1977 when maximum temperatures were about $40^{\circ} \mathrm{C}$.

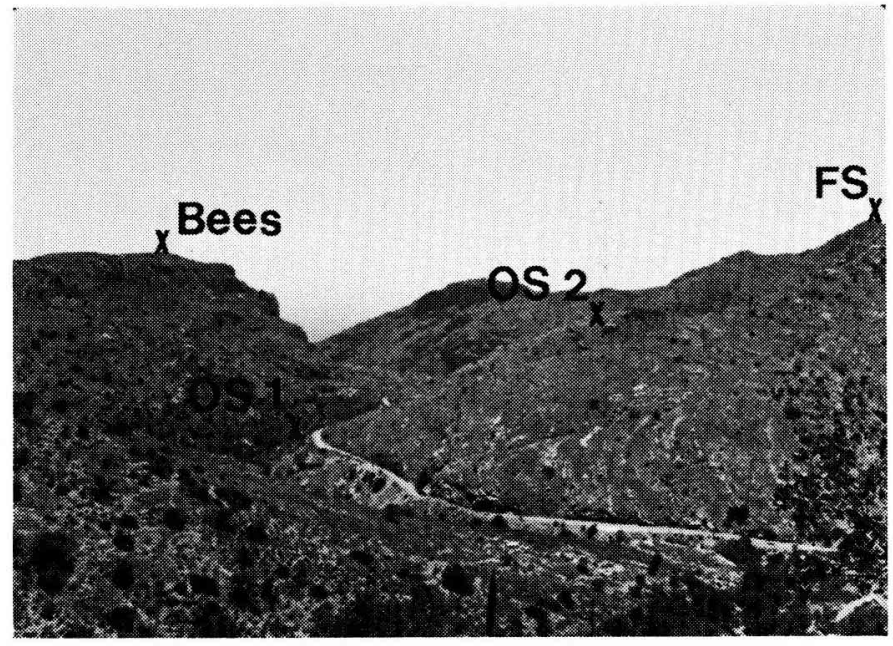

Fig. 1. - Study area located in Molino Canyon

in the Santa Catalina Mountains, Tucson, Arizona.

The direction in which the picture is taken is due south.

The bottom of the canyon is sloping down toward south

and opens in the Tuscon desert (background).

The bees were located on the east rim (bees).

The feeding station was established on the opposite rim (FS,

(OS-1, OS-2) observation stations. 


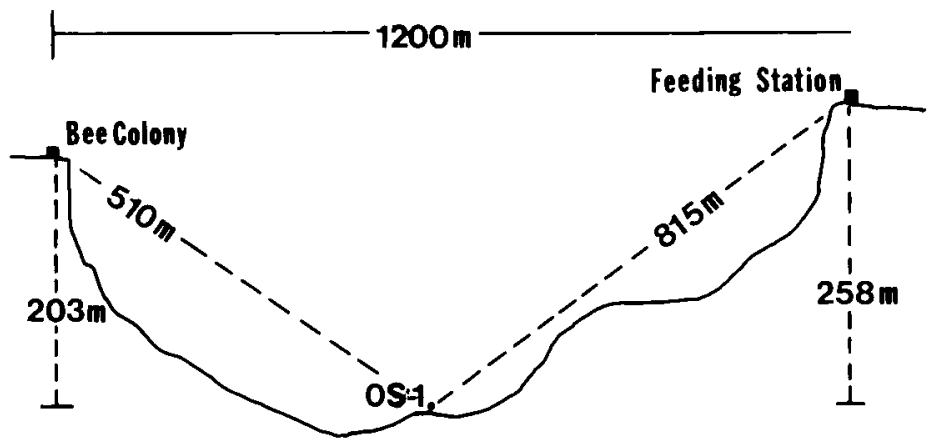

Fig. 2. - Cross section of Molino Canyon.

The drawing shows the same perspective as Fig. 1.

Elevation at OS-1 is $1,195 \mathrm{~m}$. The figures represent

the shortest lines between the given points.

Approximately 1,500 honey bees (Apis mellifera $\mathrm{L}$.) were in a one-comb observation hive placed on the east rim of the canyon. Thirty bees from this hive were trained to a $2 \mathrm{~m}$ sugar solution and step-guided across the canyon. Along with a feeder (Renner vessel) the feeding station included a $10 \mathrm{~cm}$ by $10 \mathrm{~cm}$ blue color plate. In the experiment in which odor was added, $2 \mathrm{~mm}^{3}$ of oil of lavender (Schmoller and Bompard, France) was put on a piece of filter paper and placed under the feeder. The lavender oil was replaced every two hours. The observation stations (Fig. 2,3) were similarly arranged with the exception that the feeder contained no sugar water.

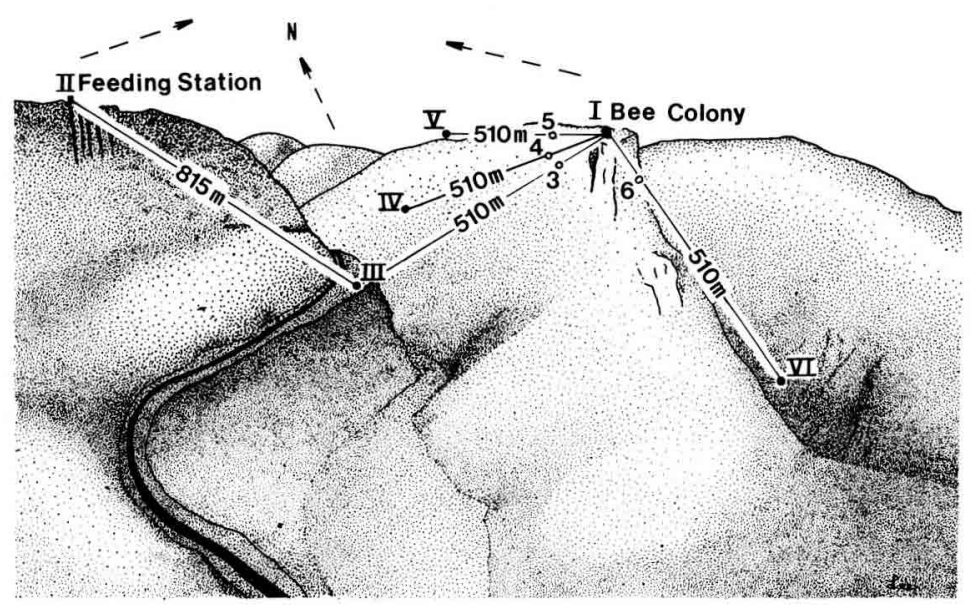

FIG. 3. - Diagram of experiment for testing the direction the recruits were leaving the hive.

Note : The left half of the drawing represents the same part

of Molino Canyon as in Figs. 1 and 2, except the perspective is due north.

Observation points III, IV, V, and VI are each $510 \mathrm{~m}$

from the bee colony. Points $3,4,5$ and 6 are each $50 \mathrm{~m}$ from the hive.

Observation points 3 and III are located on a straight line from the hive to the feeding station (due west).

The direction toward 5 and $\mathrm{V}$ is due north and that toward 4 and IV is east.

The dashed arrows indicate the wind direction. 
Observers were simultaneously positioned at the hive, the feeding station and the observation stations, and were equiped with painting kits and two-way radios. When leaving or approaching the feeding station or hive, bees were also watched with binoculars.

Each of the bees step-guided across the canyon were marked with a label showing an individual number, and each time one reached the feeding station, a dot was painted on the abdomen. Every bee noted at one of the observation stations was captured and individually painted. All newcomers arriving at the feeding station were caught and killed. Additional methodological details are provided with the individual experiments.

\section{RESULTS}

\section{The Significance of Odor Added to the Food Source}

We evaluated the significance of odor cues at the food source by presenting the bees two different orientation situations. First, odor added to the food, and second, no odor added to the food.

When the feeding station was established on the west rim of the canyon (FS, Fig. 1) all bees arriving at the feeding station and the observation station (OS-1, Fig. 2) were recorded. Within one hour observation time, 102 recruits were captured at the feeding station. Twenty-six of them had been painted at OS-1. The experiment was repeated the next day with similar results of 88 recruits at the feeding station, twenty of these bees having been marked at the halfway point OS-1.

A series of heavy rainstorms killed all the foraging bees requiring another group to be step-guided across the canyon. The feeding station and the observation station were established at the same sites, but no scent was added; only a blue color plate was put under the feeder. The same scentless arrangement was used at OS-1. On the day of the test the weather was clear and warm, similar to the previous experiments. Again, the recruitment rate for one hour was recorded. Thirty-six recruits were counted at the feeding station. Thirty of these bees had passed OS-1. In addition, 10 more recruits were noted at OS-1; however, these bees did not arrive at the feeding station. A repetition of this experiment showed 28 recruits at the feeding station, twenty of these recruits were painted at OS-1. Eight more bees noted at this station did not show-up at the food source. In summation, a greater number of recruits reached the feeding station when odor was added to the food. However, a substantial number of recruits still found the food without odor being added.

\section{Flight Paths of Recruits Approaching the feeding Station}

Observing arrival and departure of bees at the hive, the half-way observation station and the feeding station revealed the overall impression that they were flying in a fairly straight line between hive and food. At the west rim of the canyon the arrival of the recruits could be easily observed as they had to ascend a $50 \mathrm{~m}$ vertical cliff. From 200 recruits approaching the feeding station, 186 hit the foot of the cliff in a range of 
$\pm 10 \mathrm{~m}$ from the point directly beneath the feeding station. Typically, the recruit bees flew up the face of the cliff in a fairly straight line. No bee was observed approaching the feeding station from downwind following the rim of the canyon.

\section{Flight Paths of Recruits Leaving the Hive}

The situation at the hive-side rim was more difficult to observe. Particularly, it was not clear whether all recruits left the hive in a straight line towards the food. Many apparently did. If recruits were leaving the hive in directions other than straight across the canyon, we expected them to fly preferentially downwind of the line between hive and feeding station. Again, 30 bees were step-guided across the canyon. Oil of lavender was added to the feeding station and to all observation stations. These scented observation stations were located at $50 \mathrm{~m}$ and $150 \mathrm{~m}$ distances from the hive (Fig. 3). Stations 4 and IV and 5 and $V$ were established to account for bees dropping downwind when leaving the hive. Stations 6 and VI represented an additional control for identifying bees which were flying at random directions in search of the food odor. Stations 3 and III were located on a straight line between feeding station and hive. In order to prevent misguiding the bees by an odor plume drifting toward the hive, no observation station was established upwind of the hive. First, the recruits crossing the canyon were recorded at $510 \mathrm{~m}$ points (Fig. 3, stations III, IV, V and VI). Within one hour, 84 recruits arrived at the feeding station. Twenty-four were marked at observation station III, which is on a straight line between hive and feeding station. No bee was noted at stations IV, V and VI. Next, we shifted to the closer observation stations (Fig. 3, points 3, 4, 5 and 6). Ninety-eight recruit bees arrived during the next hour at the feeding station. Thirty-five bees had passed point 3; two more noted at point 4 . No bee was seen at stations 5 and 6.

These findings suggested that only a small part of the recruit pool was using a route downwind from the direct line between hive and food.

\section{DISCUSSION AND CONCLUSIONS}

Our findings show that odor is a very important factor in the orientation process of recruit bees. Upon excluding the oil of lavender from the feeding station, far less recruits were successful in locating the food source. However, we did not observe the drastic drop in recruitment reported by WENNER et al., (1969) and FRIESEN (1973) which apparently led WENNER (1974) to conclude that without odor, recruits cannot find a food site. Our observations agree more closely with GoulD's et al., (1970) findings which demonstrated recruitment to unscented solutions.

Our conclusion is that odor does not play a singular, but a supplementary role in honey bee recruitment and locating a food source.

We think that the size of the canyon, with its crosswind situation, provided us with an approach with to scrutinize WenNER's (1974) "odor population" model. Our 
findings do not confirm Wenner's statements that recruits always arrive at a food source from downwind and that bees drop downwind from the hive to pick-up the odor to which they had been recruited (WENNER, 1974; WENNER, 1968). We also did not find evidence to support FrIESEN's (1973) and WENNER's (1974) findings that a " recruit pool " would develop downwind of the flight path of the foragers. We observed the recruits flying preferentially along the line between the hive and food.

As for WENNER's (1974) " aerial-pathways ", it is difficult to understand how they could have served the recruits in our experiments to navigate across the canyon. Provided that the crosswind would not have dispersed it, the odor trail would have been blown away and drifted downwind. Consequently, recruits orienting along the " aerialpathway " must have used a flight path downwind of the line between feeding station and hive, which we did not observe. Considering our previous findings BogDany and TABER, III, in print) that experienced foragers were flying the shortest route between hive and feeding station, the efficiency of an " aerial-pathway " appears even more doubtful. In particular, it is unclear how the recruits flying close to the ground some $200 \mathrm{~m}$ straight under the forager's route could have utilized odor cues from their aerial-pathway. Provided that the odor tended to sink, it would have hit the ground in a line downwind of the actual flight path of the recruits.

Our conclusion is that the recruits navigating across the canyon were utilizing directional information other than olfactory cues. We tend to agree with EsCH and BASTIAN (1970) that recruits already " knew » the location of the food when leaving the hive.

Received in January 1979

\section{ACKNOWLEDGMENTS}

The success of these experiments relied upon the assistance of many individuals in observing the bees across the vast canyon. We thank H. Spangler, A. Zeltzer, J. Cummings, R. Schmalzel, J. Merkle, R. Scheller, and M. SpivaK. This research was supported by a Deutsche-Forschungs Gemeinschaft Fellowship. Illustrations by Lee OLsoN.

\section{RÉSUMÉ}

L'IMPORTANCE DE L'ODEUR POUR L'ORIENTATION DES ABEILLES A TRAVERS UN CAÑON

Un groupe de 30 abeilles (Apis mellifica L.) a été guidé pas à pas à travers un cañon large de $1200 \mathrm{~m}$ et profond de $200 \mathrm{~m}$ et continuellement balayé par des vents dans sa longueur. Une source de nourriture a été installée sur la rive opposée du cañon et les abeilles recrutées ont été observées et marquées indi- 
viduellement en diverses stations de contrôle. Dans la première expérience on a ajouté de l'essence de lavande à la source de nourriture; en une heure 128 recrues y sont parvenues. Lorsque dans un test suivant l'odeur a été supprimée, seules 36 recrues ont été dénombrées à la source de nourriture. En répétant ces tests, on a obtenu 88 recrues à la source de nourriture avec odeur et 28 lorsqu'aucune odeur n'était ajoutée. Ces résultats suggèrent que l'odeur joue un rôle important chez les abeilles dans la localisation d'une source de nourriture éloignée. Néanmoins les recrues n'ont pas nécessairement besoin qu'une odeur soit ajoutée à la source de nourriture pour localiser celle-ci.

On a remarqué que les recrues se dirigeaient vers la source de nourriture suivant un chemin assez rectiligne entre la ruche et la source de nourriture. Aucune abeille n'a été vue se diriger vers la source de nourriture dans le sens du vent. Afin d'étudier les directions selon lesquelles les recrues quittaient la ruche, on a installé 8 stations d'observation. Quatre d'entre elles étaient situées à une distance de $510 \mathrm{~m}$ de la ruche dans diverses directions. En une heure d'observation, 24 recrues sont passées à la station située sur la ligne droite entre la ruche et la source de nourriture, tandis qu'aucune abeille n'a été vue aux autres stations. En se plaçant aux 4 points d'observation situés à $50 \mathrm{~m}$ de la ruche, on a dénombré 35 abeilles à la station situee entre la source de nourriture et la ruche et deux abeilles à l'une des stations situées au vent.

Ces résultats suggèrent que seule une petite partie des abeilles recrutées volaient au vent entre la ruche et la nourriture. On suppose que les abeilles recrutées utilisaient en traversant le cañon des indices d'orientation autres que la seule odeur.

\section{ZUSAMMENFASSUNG}

\section{DIE BEDEUTUNG DES DUFTES FÜR DIE ORIENTIERUNG DER BIENEN BEIM ÜBERFLIEGEN EINES CANYONS}

Eine Gruppe von 30 Honigbienen (Apis mellifera L.) wurde schrittweise über einen $1200 \mathrm{~m}$ breiten und $200 \mathrm{~m}$ tiefen Canyon dressiert, in dem ein ständiger Seitenwind (quer zur Flugrichtung) herrscht. Nach Einrichtung einer Futterstelle am gegenüberliegenden Rand des Canyons wurden neu angeworbene Bienen an verschiedenen Beobachtungsstationen beobachtet und individuell markiert. Im ersten Experiment wurde dem Futter Lavendelöl beigegeben. Innerhalb 1 Stunde erschienen 128 Neulinge bei der Futterstelle. Als in einem folgenden Test der Duft weggelassen wurde, konnten nur 36 Neulinge an der Futterstelle gezählt werden. Die Wiederholung ergab mit Duft 88 Neulinge an der Futterstelle, ohne Duft 28 Neulinge. Diese Ergebnisse weisen darauf hin, dass der Duft für die Neulinge wichtig ist, wenn sie eine entfernte Futterstelle lokalisieren. Der Duft ist jedoch für die Biene keine unerlässliche Voraussetzung, um eine Futterstelle zu finden.

Es wurde beobachtet, dass die Neulinge die Futterstelle in einer ziemlich geraden Linie zwischen Stock und Futterplatz anflogen. Es wurden keine Bienen beobachtet, die die Futterstelle aus der Richtung des Windes erreichten. Um die Richtung zu prüfen, in der die Bienen von ihrem Stock wegflogen, wurden 8 Beobachtungsstationen eingerichtet. Vier von ihnen wurden in einer Entfernung von $510 \mathrm{~m}$ in verschiedener Richtung vom Stock aufgestellt. Innerhalb einer Stunde passierten 24 Neulinge die Beobachtungsstation auf der direkten Verbindungslinie zwischen Stock und Futterstelle. An den anderen Beobachtungsstationen wurde keine einzige Biene gesehen. An den 4 Beobachtungsstationen in einer Entfernung von $50 \mathrm{~m}$ vom Stock wurden 35 Bienen an der Station zwischen Futterstelle und Stock beobachtet und 2 Bienen an einer Station in der Windrichtung.

Diese Ergebnisse lassen darauf schliessen, dass nur ein kleiner Teil der neu angeworbenen Bienen auf einer Linie in Windrichtung zwischen Bienenstock und Futterstelle flog. Es wird angenommen, dass die angeworbenen Bienen beim Überqueren des Canyons andere Orientierungsmittel benutzten als allein den Duft. 


\section{REFERENCES}

BOGdANY F. J., TABer III S. - Orientation of honey bees in a canyon. In print.

EsCh H., Bastian J. A., 1970. - How do newly recruited honey bees approach a food site? Z. vergleich. Physiol., 68, 175-181.

FrIESEN L. J., 1973. - The search dynamics of recruited honey bees. Biol. Bull., 144, 107-131.

FrISCH K. von, 1923. - Über die "Sprache" der Bienen, eine tierpsychologische Untersuchung. Zool. Jahrb. Abt. Allg. Zool. Physiol. Tiere, 40, 1-186.

Frisch K. von, 1967a. - The dance language and orientation of bees. Harvard Univ. Press. Cambridge.

Frisch K. von, 1967b. - Honey bees : do they use the direction and distance information provided by their dancers? Science, 158, 1072-1076.

Gould J. L., Henerey M., Macleoad M. C., 1970. - Communication of direction by the honey bee. Science, 169, 544-554.

Gould J. L., 1976. - The dance language controversy. Quart. Rev. Biol., 51, 211-214.

LiNDAUER M., 1971. - The functional significance of the honey bee waggle dance. Am. Nat., 105, 89-96.

Wells P. H., WenNer A. M., 1971. - Influence of food scent on foraging honey bees. Physiol. Zool., 44, 191-209.

Wenner A. M., 1968. - Honey bees. In T. A. Sebeok (ed.). Animal Communication, p. 217-243. Indiana Univ. Press., Bloomington.

WenNer A. M., 1974. - Information transfer in honey bees : a population approach. In L. Krames, P. Pliner, and T. Alloway (eds.). Nonverbal Communication, Vol. 1, p. 133-169. Plenum, New York.

WenNer A. M., Wells P. H., JoHnson D. L., 1969. - Honey bee recruitment to food sources : olfaction or language? Science, 164, 84-86. 